PUSTABIBLIA: Journal of Library and Information Science

ISSN 2549-3493 (Print); ISSN 2549-3868 (Online)

DOI: http://dx.doi.org/10.18326/pustabiblia.v3i2.175-187

SK Dirjen Risbang-Kemristekdikti No 23/E/KPT/2019 (Peringkat 4 SINTA)

\title{
Eksistensi Pustakawan Sekolah di Era Digital
}

\author{
Latifah Wahyuni ${ }^{1^{*}}$ \\ Pustakawan SMP N 7 Magelang \\ *latifahwahyunimgl@gmail.com
}

\begin{abstract}
In today's digital era, every activity of a person or organization is inseparable from sophisticated devices and the internet. The paperless era seems to have been implicated in every link of life including at school. At present many schools use devices and personal computers as the main tools for making various things related to learning activities such as school exam materials, daily assessments, and final semester assessments. The clearest example is the UNBK (Computer Based National Examination). The Ministry of Education has even distributed 1.75 million devices to a number of schools in order to expedite the school digitalization program called Rumah Belajar. The penetration of school digitalization has not yet been matched by the readiness of the school library and the ability of school librarians so that the school library and school librarian seem to be left behind and abandoned. Therefore, the author is interested in researching this matter. By using descriptive research methods the writer describes the existence of school library in the digital era and the existence of school librarians in the midst of the onslaught of information and technology. In order for school librarians not to be left behind and their existence to be calculated and needed in every sector, of course school librarians must upgrade themselves and transform into librarians who have the ability of technology, negotiation, collaboration and literacy.
\end{abstract}

\section{Abstrak}

Di era digital saat ini, setiap kegiatan dan aktifitas seseorang maupun organisasi tidak terlepas dari gawai canggih dan internet. Era tanpa kertas sepertinya telah menggejala di setiap lini kehidupan tak terkecuali di sekolah. Saat ini banyak sekolah 
yang menjadikan gawai dan personal computer untuk dapat membuat berbagai hal berkaitan dengan pembelajaran, materi ujian sekolah, penilaian harian, hingga Penilaian Akhir Semester (PAS). Contoh nyata yang paling jelas adalah UNBK (Ujian Nasional Berbasis Komputer). Bahkan kementrian pendidikan telah membagikan 1,75 juta gawai ke sejumlah sekolah guna memperlancar program digitalisasi sekolah yang bernama rumah belajar. Penetrasi digitalisasi ke sekolah ternyata belum diimbangi dengan kesiapan perpustakaan sekolah dan kemampuan pustakwan sekolah sehingga menjadikan perpustakaan sekolah dan pustakawan sekolah terkesan tertinggal dan ditinggalkan. Oleh karena itu penulis tertarik untuk meneliti ini. Dengan menggunakan metode penelitian desriptif penulis mengambarkan tentang keberadaan perpustakaan sekolah di era digital dan eksistensi pustakawan sekolah ditengah gempuran informasi dan teknologi. Dan agar pustakawan sekolah tidak tertinggal dan eksistensinya diperhitungkan dan dibutuhkan disetiap sektor, tentunya pustakawan sekolah harus mengupgrade diri dan bertransformasi menjadi pustakawan yang memiliki kemampuan teknologi, negosiasi, kolaborasi dan literate.

Keywords: Perpustakaan Sekolah, Eksistensi Pustakawan Sekolah, Era Digital, Transformasi

\section{Pendahuluan}

Kemajuan perkembangan teknologi saat ini tentunya sangat besar dampaknya dalam kehidupan masyarakat tak terkecuali dalam dunia pendidikan dan perpustakaan di indonesia. Dalam era digital sekarang ini, keseharian kita selalu berdampingan dengan teknologi dan internet. Keberadaan teknologi mempermudah manusia mencapai segala yang diinginkannya. Hanya dengan gawai di tangan seseorang dapat melakukan banyak hal. Bahkan remaja dan anak-anak sekarang sulit dipisahkan dari smartphone /gawai canggih. Saat ini telepon genggam tak sebatas berfungsi untuk menelpon dan mengirim pesan secara tertulis atau saling berbagi kejadian yang sedang viral. Kini android jauh memiliki multi fungsi. Beberapa perangkat yang selama ini akrab dengan kehidupan kita seperti kalender, jam tangan, kalkulator, stopwatch, media cetak, jasa jual beli, surat menyurat, kini diambil alih oleh Android.

Gejala dunia tanpa kertas juga mulai memasuki sekolah dan ruang kelas belajar anak. Kini para guru mulai bergerak dari kertas ke digital. Dari 
kertas ke android. Ujian Nasional Berbasis Komputer (UNBK) adalah salah satunya. Dalam dunia yang lebih luas, Data Pokok Pendidikan (Dapodik) yang dianggap sebagai satu-satunya pangkalan data yang paling valid saat ini, sudah menunjukkan fakta tentang pergeseran itu. Gawai dan personal computer menjadi sarana untuk dapat membuat berbagai hal berkaitan dengan pembelajaran. Materi ujian sekolah, Penilaian Harian, hingga Penilaian Akhir Semester. Semua bisa dikoneksikan dengan internet, untuk selanjutnya anak-anak dapat belajar dan mengerjakan soal-soal lewat Android masing-masing. Hal tersebut sejalan dengan program kementrian pendidikan sebagaimana dirilis kompas tanggal 10 September 2019, bahwa kementrian pendidikan membagikan 1,75 juta gawai ke sejumlah sekolah di pinggiran yang memiliki kinerja bagus, ada 3600 sekolah yang mendapat bantuan tersebut. ${ }^{1}$ Program digitalisasi sekolah itu bernama rumah belajar. Dan kebetulan sekolah kami, SMP N 7 Magelang termasuk yang mendapat bantuan gawai tersebut sejumlah 200 tablet.

Ini adalah fenomena di era digital, dimana anak-anak saat ini semakin jarang bersentuhan dengan kertas, dan lebih mengandalkan kotak ajaib, si telepon pintar. Lalu, bagaimana dengan buku cetak sebagai media informasi dan referensi belajar siswa?. Tidak bisa dipungkiri saat ini banyak buku digital (ebook) yang mudah diakses melalui gawai dan perangkat elektronik. Selain itu dalam mengerjakan tugas-tugas siswa lebih cenderung mencari dan bertanya pada mbah google dari pada mencari informasi di buku teks. Tak heran, dalam penelitian Cambridge International yang melibatkan 502 pelajar Indonesia bahwa lebih dari dua pertiganya (62\%) menggunakan gawai di kelas dan bahkan lebih banyak lagi dari mereka (81\%) menggunakannya untuk mengerjakan pekerjaan rumah. Siswa Indonesia menduduki peringkat tertinggi secara global selaku pengguna ruang IT/komputer (40\%) di sekolah. Mereka juga menduduki peringkat kedua tertinggi di dunia dalam penggunaan komputer desktop (54\%), setelah Amerika Serikat. ${ }^{2}$

\footnotetext{
${ }^{1}$ Risma Riyadi, 2019. Kemendikbud bakal bagikan 1,75 juta gawai ke sekolah, berita kompas tanggal 10 september 2019.

${ }^{2}$ Mulyani, "Riset Cambridge: Pelajar Indonesia pengguna teknologi tertinggi di bidang pendidikan”, //http.news.okezone.com/read/2018/11/21/65/1980696/riset-cambridge-pelajar-
} 
Lalu bagaimana dengan keberadaan perpustakaan sekolah, yang koleksinya masih didominasi oleh media cetak/kertas?. Dan bagaimana eksistensi pustakawan sekolah ditengah gempuran informasi dan teknologi digital yang semakin canggih?

Kehadiran internet telah memunculkan optimisme yang sangat tinggi terhadap kemudahan dan kecepatan akses terhadap informasi. Di sisi lain, euporia terhadap kekuatan internet memunculkan pesimisme yang juga tinggi terhadap keberadaan Perpustakaan sehingga memunculkan keraguan, masih perlukah perpustakaan apabila kita bisa mendapatkan semua informasi melalui internet tanpa pergi ke perpustakaan? Ini menjadi tantangan bagi pustakawan. ${ }^{3}$ Tak terkecuali pustakawan sekolah, adanya program digitalisasi sekolah dan dalam menghadapi era digital tentunya memerlukan kualifikasi khusus dari para pustakawan sekolah agar dapat beradaptasi dengan era dan generasi digital.

Laju perkembangan teknologi digital adalah sesuatu realita yang tidak bisa kita hindari, karena akan bertumbuh seiring kemajuan ilmu pengetahuan. Keberadaan internet dan gawai canggih adalah salah satu inovasi teknologi yang diciptakan manusia untuk mempermudah kebutuhan manusia. Seiring pesatnya perkembangan teknologi, membuat pengguna internet di indonesia pun ikut melambung tinggi. Hal ini sesuai dengan survai yang dilakukan Asosiasi Penyelenggara Jasa Internet (APIJI), jumlah pengguna internet di Indonesia tumbuh 10,12 persen, survei ini melibatkan 5.900 sampel dengan margin of error 1,28 persen. Data lapangan ini diambil selama periode Maret hingga 14 April 2019. Dari total populasi sebanyak 264 juta jiwa penduduk Indonesia, ada sebanyak 171,17 juta jiwa atau sekitar 64,8 persen yang sudah terhubung ke internet. ${ }^{4}$.

Indonesia-teknologi-dibidang-pendidikan. Download pada 12 november 2019

${ }^{3}$ Nuning khoirunnisa, "Kualifikasi pustakawan di era digital https://www.academia. edu/27643422/Kualifikasi_Pustakawan_di_Era_Digital, downdload pada 14 November 2019

${ }^{4}$ Pratomo Yusuf "APJII: Jumlah Pengguna Internet di Indonesia Tembus 171 Juta Jiwa", https://tekno.kompas.com/ read/2019/05/16/03260037/apjii-jumlah-pengguna-internet-di-indonesiatembus-171-juta-jiwa 
Yang perlu dilakukan dalam menghadapi kemajuan teknologi dan era digital hanya menyambutnya dengan berbagai kesiapan. Apakah pustakawan sekolah sudah siap menghadapi ini?. Jika kita amati masih ada kesenjangan antara laju perkembangan teknologi dengan kesiapan untuk memanfaatkannya. Digitalisasi sekolah sebagai program baru kementrian pendidikan merupakan tantangan baru bagi pustakawan sekolah untuk berperan aktif, tentunya diperlukan kesiapan teknis dan psikologi untuk menghadapinya. Pustakawan sekolah harus berbenah dan memantaskan diri dengan cara mengupgrade diri dan bertransformasi.

\section{Tinjauan Pustaka}

Secara sederhana pustakawan sekolah adalah pustakawan yang bekerja di perpustakaan sekolah. Jika kita merujuk pada UU Sisdiknas tahun 2003, pustakawan perpustakaan sekolah masuk dalam kategori tenaga kependidikan. Tenaga kependidikan meliputi: pengelola satuan pendidikan, penilik, pamong belajar, pengawas, peneliti, pengembang, pustakawan, laboran dan teknisi sumber belajar ${ }^{5}$. sedangkan menurut Suherman pustakawan sekolah adalah tenaga kependidikan berkualifikasi serta profesional yang bertanggung jawab atas perencanaan dan pengelolaan perpustakaan sekolah, didukung oleh tenaga yang mencukupi, bekerja sama dengan semua anggota komunitas sekolah, dengan berhubungan dengan perpustakaan umum, dan lain-lainnya. ${ }^{6}$

Dari pengertian di atas bahwa pustakawan sekolah harus memiliki kualifikasi dan professional. Menurut kamus besar bahasa Indonesia kualifikasi memiliki beberapa pengertian yaitu 1) pendidikan khusus untuk memperoleh suatu keahlian; 2)keahlian yang diperlukan untuk melakukan sesuatu (menduduki jabatan dan sebagainya); 3)tingkatan; 4)pembatasan; penyisihan (dalam olah raga $)^{7}$.

\footnotetext{
${ }^{5}$ Darmono, 2001. Manajemen dan Tata Kerja Perpustakaan Sekolah. Jakarta: Grasindo

${ }^{6}$ Suherman, 2009. Perpustakaan Sebagai Jantung Sekolah Referensi Pengelolaan Perpustakaan Sekolah, Bandung: MQS Publishing

${ }^{7}$ Depdiknas. 2011. Kamus Besar Bahasa Indonesia. Jakarta: Balai Pustaka.
} 
Sedangkan professional mengacu pada profesi dan keahlian, menurut KBBI profesional memiliki arti (1) bersifat profesi (2) memiliki keahlian dan keterampilan karena pendidikan dan latihan, (3) beroleh bayaran karena keahliannya itu'. Seseorang dikatakan profesional ketika memiliki 3 hal pokok dalam dirinya, yaitu: skill, knowledge, dan Attitude Skill disini berarti seseorang itu benar-benar ahli di bidangnya. Knowledge, tak hanya ahli di bidangnya, tetapi ia juga menguasai dan minimal tahu dan berwawasan tentang ilmu-ilmu lain yang berhubungan dengan bidangnya. Sedangkan Attitude, bukan hanya pintar dan cerdas tetapi dia juga punya etika yang diterapkan dalam bidangnya.

Karena pustakawan sekolah bekerja disekolah maka selain memiliki pendidikan khusus ilmu perpustakaan yang profesional dan berkualifikasi, dia juga harus memiliki pengetahuan dan kemampuan tambahan dibidang teori pendidikan, metodologi pembelajaran dan hal-hal yang berkaitan dengan dunia pendidikan termasuk program pendidikan seperti program digitalisasi sekolah. Selain itu penguasaan teknologi juga kemampuan penting lain yang harus dikuasai, apalagi diera digital saat ini dimana serba cepat mudah dan instan, hal tersebut menjadi tuntutan dan tantangan tersendiri bagi pustakawan sekolah dalam menunjang digitalisasi sekolah yang sedang berjalan.

Digitalisasi sekolah merupakan salah satu upaya pemerintah dalam menghadapi era digital dan industry 4.0. Istilah era digital sendiri merupakan istilah yang sering digunakan dalam kemunculan digital, jaringan internet khususnya teknologi informasi komputer. Era digital juga sering digunakan untuk menggambarkan teknologi digital. Adapun kondisi pada era digital merupakan era dimana semua manusia dapat saling berkomunikasi sedemikian dekat walaupun saling berjauhan. Kita dapat dengan cepat mengetahui informasi tertentu bahkan real time. Menurut Wikipedia, era digital bisa juga disebut dengan globalisasi. Globalisasi adalah proses integrasi internasional yang terjadi karena pertukaran pandangan dunia, produk,

${ }^{8}$ ibid 
pemikiran, dan aspek-aspek kebudayaan lainnya yang banyak disebabkan oleh kemajuan infrastruktur telekomunikasi, transportasi dan internet ${ }^{9}$.

\section{Metode}

Metode penelitian yang digunakan dalam artikel ini adalah metode penelitian deskriptif dimana dengan metode ini penulis menyajikan gambaran lengkap mengenai eksistensi pustakawan sekolah di era digital. Selain itu untuk mengeksplorasi dan klarifikasi mengenai keberadaan atau eksistensi pustakawan sekolah di era digital, dengan jalan mendeskripsikan sejumlah variabel yang berkenaan dengan masalah dan unit yang diteliti antara fenomena yang diuji. Dalam penelitian ini, peneliti telah memiliki definisi jelas tentang pustakawan sekolah, eksistensi dan era digital dan akan menggunakan pertanyaan who dalam menggali informasi yang dibutuhkan.

Tujuan dari penelitian deskriptif ini adalah menghasilkan gambaran akurat tentang eksistensi pustakawan sekolah di era digital, menggambarkan mekanisme sebuah proses atau hubungan, memberikan gambaran lengkap baik dalam bentuk verbal atau numerikal, menyajikan informasi dasar akan suatu hubungan, menciptakan seperangkat kategori dan mengklasifikasikan subjek penelitian, menjelaskan seperangkat tahapan atau proses, serta untuk menyimpan informasi bersifat kontradiktif mengenai subjek penelitian.

\section{Hasil dan Pembahasan}

Kondisi perpustakaan terutama perpustakaan sekolah di Indonesia memiliki kondisi yang beragam. Begitupun keberadaan pengelolanya, mulai dari tingkat pendidikan, status kepegawaian dan kemampuan serta ketrampilan yang dikuasai pun beragam. Ada beberapa pengelola perpustakaan sekolah yang sudah berstatus fungsional pustakawan, namun masih banyak pula tenaga pengelola perpustakaan yang berlatar pendidikan SMA sederajat atau non perpustakaan. Bahkan dibeberapa sekolah tidak ada pengelola

${ }_{9}^{9}$ http://id.wikipedia.org/wiki/era-digital, diakses tanggal 16 November 2019 
perpustakaan secara khusus, yang ada guru yang memiliki jam kurang dari 24 jam kemudian mendapat tugas tambahan/ sampiran mengelola perpustakaan sekolah. Kondisi tersebut menjadi catatan tersendiri untuk mengembangkan dan memperbaiki tenaga pengelola perpustakaan. Lowongan untuk pustakawan sekolah harus diberi posri lebih banyak oleh pemerintah, mengingat tuntutan akan kebutuhan informasi dan perkembangan teknologi yang pesat. Maka keberadaan perpustakaan sekolah yang bagus akan sangat berpengaruh terhadap keberhasilan pendidikan di sekolah. Dan kondisi perpustakaan sekolah yang bagus harus didukung dengan pengelola perpustakaan yang mumpuni dan professional dibidangnya.

Dan di era digital ini keberadaan perpustakaan sekolah harus mampu bersaing dan berkolaborasi untuk memenuhi tuntutan pengguna yang sebagian besar generasi y, generasi yang tidak bisa dipisahkan dari gawai canggih dan internet. baik itu untuk kehidupan sehari-hari maupun pada kegiatan belajar dan bisnis.

Apalagi dengan adanya program digitalisasi sekolah, dimana era tanpa keras mulai diterapkan di beberapa kegiatan belajar mengajar. Maka, pustakawan sekolah harus mengupgrade diri dan bertransformasi menjadi pustakawan yang memiliki kemampuan teknologi, negosiasi, kolaborasi dan literate. Pustakawan sebagai rodanya perpustakaan sekolah, dan sebagai bagian dari tenaga kependidikan memiliki peran penting dalam tercapainya tujuan pendidikan serta visi misi sekolah.

Penguasaan literasi dan informasi bagi pustakawan juga sangat penting, karena mayoritas masyarakat berpendapat bahwa kebutuhan akan informasi apapun akan tetap terpenuhi tanpa perpustakaan dan pustakawan. Hal demikian dapat terjadi dikarenakan oleh penyebarluasan informasi tak berbatas dari internet. Padahal, tidak semua informasi yang ada di internet itu benar adanya. Sebab informasi dari internet sendiri bisa saja datang dari pihak yang belum tentu kompeten di bidangnya. Namun, paradigma sekarang seolah senada dengan pernyataan tersebut. Mereka seolah tidak puas dengan eksistensi perpustakaan dan pustakawan akibat rasa tak puas mereka akan kinerja pustakawan. Pustakawan dianggap selalu lamban dalam menyediakan 
dan menjawab informasi yang dibutuhkan oleh pengguna. Mereka cenderung memilih internet yang menyediakan informasi secara cepat dan mudah. Disinilah tantangan terbesar bagi pustakawan untuk membuktikan kepada masyarakat luas bahwa pustakawan memiliki peran yang strategis dalam era digital dan informasi saat ini. Pustakawan sebagai kurator ilmu pengetahuan dan informasi harus mampu memberikan informasi secara cepat, tepat, benar, akurat dan bisa dipertanggungjawabkan. Sehingga keberadaannya diperhitungkan diberbagai sektor.

\section{a. Transformasi Pustakawan Sekolah}

Pustakawan sekolah masih identik dengan istilah penjaga perpustakaan, banyaknya perpustakaan sekolah yang belum memiliki pustakawan atau tenaga perpustakaan yang memiliki basic pendidikan perpustakaan sehingga lebih banyak diisi oleh tenaga lulusan SMA/SMK atau guru yang memiliki jam mengajar kurang dari 24 jam. Hal tersebut berpengaruh terhadap layanan dan pengembangan perpustakaan sekolah. Perpustakaan sekolah cenderung stagnan dan hanya berkutat pada teknis administrative. Padahal di era digital ini kebutuhan informasi yang cepat, mudah dan akurat menjadi tuntutan semua orang. Dan kenyataannya banyak siswa lebih mengandalkan internet dalam mencari dan menemukan informasi baik untuk tugas, pendidikan maupun hiburan. Internet juga dapat menjadi dunia kebebasan bagi semua orang untuk berekspresi maupun mencari informasi baik yang sifatnya positif ataupun negatif. Selain itu, tak ada pihak yang berwenang untuk bertanggung jawab terhadap validitas informasi yang dikirim dan ditemukan. Di sisi lain, potensi internet sebagai penyedia informasi pun cukup mengagumkan sebab selalu tersedia dan mampu diakses selama 24 jam dalam seharinya. Tak hanya sebatas itu, internet juga bisa diakses dimana saja dan nyaman bagi penggunanya.

Adanya tuntutan teknologi dan digitalisasi sekolah peran perpustakaan pun semakin luas dan kompleks. Perpustakaan sekolah yang awalnya hanya sebatas pelayanan buku dan informasi tekstual kini harus memfasilitasi kebutuhan digital. Oleh karena itu, pustakawan sekolah harus mengupgrade 
diri dan bertransformasi. Mengupgrade diri dalam arti meningkatkan kemampuan diri dan ketrampilan teknis serta teknologi informasi guna mengoptimalkan pelayanan, karena perpustakaan sekolah saat ini membutuhkan pengelola yang mampu mengembangkan fungsinya sesuai dengan perkembangan teknologi yang sedang berkembang. Dengan begitu, Perpustakaan sekolah dapat bersaing dengan sumber informasi lain dan mampu menjadi sumber informasi yang optimal, akurat dan dapat dipertanggungjawabkan. Beberpa langkah yang dapat dilakukan pustakawan sekolah dalam rangka mengupgrade diri untuk meningkatkan kemampuan dan ketrampilan adalah:

1) Melanjutkan pendidikan ke jenjang lebih tinggi

Dengan melanjutkan pendidikan atau kuliah lagi ke jenjang lebih tinggi merupakan salah satu cara dalam menambah keilmuan, wawasan, kemampuan dan ketrampilan. Bagi pengelola perpustakaan yang baru memiliki ijazah diploma perpustakaan dapat melanjutkan ke sarjana perpustakaan, yang sudah berijazah sarjana pun dapat melanjutkan ke pasca sarjana, sehingga ilmu yang didapat semakin meningkat karena perkembangan ilmu pengetahuan bersifat dinamis.

2) Mengikuti berbagai pelatihan dan seminar

Mengikuti berbagai pelatihan dan seminar merupakan cara paling efektif dan cepat dalam meningkatkan kemampuan dan ketrampilan diri. Ada banyak pendidikan pelatihan dan seminar, baik yang berkaitan tentang teknis pengelolaan perpustakaan, teknologi informasi maupun literasi yang dapat diikuti oleh pustakawan sekolah.

3) Mengoptimalkan jejaring dan komunitas

Jejaring antar pustakawan dan komunitas merupakan wadah yang cukup aktif dalam melakukan pertukaran dan penyebaran informasi dan ilmu pengetahuan. Dengan mengoptimalkan jejaring dan komunitas pustakawan bisa saling berbagi pengetahuan, informasi dan ketrampilan. Kemampuan pustakawan secara otomatis meningkat dengan adanya transfer ilmu, informasi dan ketrampilan dalam perkembangan dan pengelolaan perpustakaan 


\section{b. Partisipasi Aktif Pustakawan dalam Digitalisasi Sekolah}

Digitalisasi sekolah merupakan program kementrian pendidikan terbaru. Pelaksanaan program ini merupakan bentuk inovasi pembelajaran berbasis digital yang dimulai dengan mempersiapkan konten atau platform yang diberi nama rumah belajar yang akan menjadi platform digital resmi dan gratis dari kemendikbud kepada publik. Program digitalisasi sekolah merupakan implementasi dari new learning yang disiapkan untuk menghadapi revolusi industry 4.0. Karakteristik new learning tersebut adalah student contered, multimedia, collaborative work, information exchange, dan critical thingking and informae decition making. Program ini nantinya akan diberlakukan disemua sekolah yang ada di Indonesia.

Kondisi ini menjadi tantangan bagi seluruh komponen sekolah tak terkecuali perpustakaan sekolah. Agar eksistensinya diakui pustakawan sekolah harus terlibat dan berpartisipasi secara aktif dalam program digitalisasi sekolah. Untuk bisa terlibat dalam program digitalisasi sekolah maka penguasaan teknologi informasi menjadi syarat mutlaknya.

Permasalahannya masih banyak pengelola perpustakaan sekolah yang memiliki kemampuan rendah dalam penguasaan teknologi informasi. Belum lagi masih adanya beberapa perpustakaan sekolah yang pelayanannya belum teroutomasi dan masih tradisional. Apalagi ke taraf digital library, tentu ini menjadi catatan penting sekaligus tantangan bagi kita semua.

\section{c. Kemas Ulang dan Alih Media Informasi}

Keberadaan internet dan hyperteks memberikan alternatif pemikiran berbeda dari pada media tercetak seperti buku majalah atau koran. Pada media tradisional ini, kita dipaksa untuk berfikir linier, bias juga runtun. Kita membaca halaman satu ke halaman selanjutnya, mengikuti logika pemikiran umum. Jika sebuah naskah dalam naskah tercetak tidak linier tidak bermakna. Media cetakan memerlukan privasi dan pemikiran yang reflektif. Sementara media elektronik memberikan keleluasaan pada pembaca untuk berfikir meloncat-loncat, berkat keunggulan taut.

Untuk menjembatani informasi bentuk tradisional dalam bentuk 
elektronik atau digital diperlukan kemas ulang dan alih media informasi. Kemas ulang informasi merupakan aktivitas mengemas kembali informasi atau mentranster dari satu bentuk ke bentuk lain dengan kemasan yang lebih menarik. Pekerjaan ini merupakan hasil dari upaya mengatasi ledakan informasi dan persaingan untuk mendukung lembaga induk dengan memberikan informasi yang cepat, tepat, dan akurat untuk mendukung pembuatan keputusan. Dengan kata lain, kemas ulang informasi merujuk pada penyajian informasi dalam bentuk yang lebih dapat dimengerti, mudah dibaca, dan dikemas dalam bentuk yang lebih dapat diterima dan digunakan.

Dalam kehidupan sehari-hari saat ini, kemas ulang informasi menjadi kegiatan penting, karena jutaan informasi diproduksi manusia setiap menit dengan kemajuan teknologi komputer dan telekomunikasi, bahkan dengan kemas ulang informasi para pemustaka mendapat kemudahan untuk lebih memahami informasi yang melimpah itu. Secara lebih rinci kemas ulang informasi mempunyai fungsi sebagai berikut:

1. Sarana pendokumentasian informasi

2. Sarana untuk memilih informasi yang bermanfaat bagi pemustaka secara sistematis

3. Sarana penyajian dan alih informasi yang lebih ekstensif

4. Alat terjemahan

5. Peluang untuk menerapkan hasil penelitian

6. Sarana penyajian informasi relevan secara langsung

\section{Kesimpulan}

Pustakawan sekolah sebagai salah satu tenaga kependidikan yang melayani kebutuhan informasi siswa, guru dan karyawan dalam upaya pencapain tujuan pendidikan dan keberhasilan visi dan misi sekolah harus mampu memenuhi tuntutan pengguna dengan cara menambah ilmu, keahlian dan ketrampilan. Dengan adanya program digitalisasi sekolah, pustakawan harus berbenah diri agar bisa mengimbangi dan memberikan layanan yang dibutuhkan dengan memperkuat kemampuan dibidang 
teknologi informasi. Pemikiran lama tentang pengelola perpustakaan sekolah sebagai penjaga buku harus diupgrade menjadi pustakawan yang memiliki keahlian mumpuni dibidang teknologi informasi dan pustakawan sekolah sebagai kurator ilmu pengetahuan yang dapat memberikan informasi secara cepat, tepat, akurat dan dapat dipertanggungjawabkan.

\section{Daftar Pustaka}

Darmono. 2001. Manajemen dan Tata Kerja Perpustakaan Sekolah. Jakarta: Grasindo

Depdiknas. 2011. Kamus Besar Bahasa Indonesia. Jakarta: Balai Pustaka. Mulyani, "Riset Cambridge: Pelajar Indonesia pengguna teknologi tertinggi di bidang pendidikan", //http.news.okezone.com/ $\mathrm{read} / 2018 / 11 / 21 / 65 / 1980696 /$ riset-cambridge-pelajar-Indonesiateknologi-dibidang-pendidikan. Download pada 12 november 2019

Nuning khoirunnisa, "Kualifikasi pustakawan di era digital, https://www. academia.edu/27643422/ Kualifikasi_Pustakawan _di_Era_Digital, downdload pada 14 November 2019

Pratomo, Yusuf. "APJII: Jumlah Pengguna Internet di Indonesia Tembus 171 Juta Jiwa", https://tekno.kompas.com/ read/2019/05/16/03260037/ apjii-jumlah-pengguna-internet-di-indonesia-tembus-171-juta-jiwa

Riyadi, Risma. 2019. Kemendikbud bakal bagikan 1,75 juta gawai ke sekolah, berita kompas tanggal 10 september 2019.

Saleh, Abdul Rahman. 2015. Pengembangan Perpustakaan Digital, Tangerang Selatan: Universitas Terbuka

Suherman, 2009. Perpustakaan Sebagai Jantung Sekolah Referensi Pengelolaan Perpustakaan Sekolah, Bandung: MQS Publishing

http://id.wikipedia.org/wiki/era-digital, diakses tanggal 16 November 2019 